\title{
Physical and Mechanical Properties of Fir and Poplar Subjected to Tall Oil and Vacuum Heat Treatment
}

\author{
Kadriye GÖKMEN ${ }^{1}$, Hüseyin SIVRIKKAYA ${ }^{1, *}$ \\ ${ }^{1}$ Department of Forest Industrial Engineering, Bartın University, Bartın, Turkey
}

\begin{abstract}
Vacuum heat treatment creates an oxygen-free environment, thus positively effects the properties of wood compared to traditional heat treatment. Crude tall oil is a non-biocidal wood preservative, composed of resin and fatty acids and improves some properties of wood such as water uptake and decay resistance. In this study, tall oil dissolved in ethanol (10\% and 20\%) for impregnation of the fir and poplar samples according to full cell method, followed by subjected to vacuum-heat treatment at $180{ }^{\circ} \mathrm{C}$ and $200{ }^{\circ} \mathrm{C}$ for 1 and $2 \mathrm{~h}$ respectively. Water uptake and mechanical tests such as bending and compression strength of untreated and treated samples were investigated. Results showed that weight percent gain (WPG) was about two times higher for tall oil treatment at $20 \%$ than $10 \%$ of tall oil. Vacuum heat treatment showed similar trend with control samples in terms of water uptake, while combined treatment of tall oil and vacuum heating lowered the water uptake. The results of mechanical tests indicated that bending strength was not affected by tall oil treatment. Combination of tall oil and vacuum heat treatment improved the compression strength.
\end{abstract}

Keywords: Tall oil, vacuum heat treatment, fir, poplar, water uptake, bending strength.

\section{Tall Yağı Emprenyesi ve Vakum Altında Isıl İşlem Yapılmış Göknar ve Kavak Odunlarının Fiziksel ve Mekanik Özellikleri}

\section{Öz}

Geleneksel ısıl işlemle karşılaştırıldığında, vakumlu ısıl işlem oksijensiz bir ortam yaratır, dolayısıyla odunun özelliklerini olumlu yönde etkiler. Ham tall yağı, reçine ve yağ asitlerinden oluşan ve odunun su alma ve çürüklük direnci gibi bazı özelliklerini iyileştiren, biyosidal olmayan bir odun koruyucudur. Bu çalışmada, göknar ve kavak odunlarının dolu hücre yöntemine göre emprenyesi için tall yağı etanolde (\%10 ve \%20) çözündürülmüş, ardından sırasıyla $180{ }^{\circ} \mathrm{C}$ ve $200{ }^{\circ} \mathrm{C}^{\prime}$ de 1 ve 2 saat süreyle vakumlu isıl işleme tabi tutulmuştur. Kontrol ve muamele edilmiş numunelerin su alma, eğilme ve basınç direnci gibi mekanik testleri incelenmiştir. Sonuçlar, tall yağının \%20 oranında kullanıldığı emprenye işlemlerinde yüzde ağırlık artışı tall yağının \%10'una kıyasla yaklaşık iki kat daha yüksek olduğunu göstermiştir. Vakumlu ısıl işlem, su alımı açısından kontrol örnekleri ile benzer bir eğilim gösterirken, tall yağı ve vakumlu ısıl işlem kombinasyonu su alımını azaltmıştır. Mekanik test sonuçları, eğilme direncinin tall yağı emprenyesinden olumsuz etkilenmediğini göstermiştir. Tall yağı ve vakumlu ısıl işlem kombinasyonu basınç direncini artırmıştır.

Anahtar Kelimeler: Tall yağı, vakumlu ısıl işlem, göknar, kavak, su alma, eğilme direnci. 


\section{Introduction}

People have continuously used the wood material to meet their needs in many areas such as small household appliances, construction material, furniture making etc. from past to present. Although, metal and plastic materials have been emerged alternative to wood with the industrial development, wood is still a desired material due to the being a renewable resource, low energy production, mechanical and elastic properties and texture. However, wood is susceptible to dimensional stability and decay resistance when subjected to higher relative humidity.

Thermal treatment is an environmentally friendly method to improve dimensional stability and decay resistance of wood under higher temperatures between $180^{\circ} \mathrm{C}$ and $260^{\circ} \mathrm{C}$ without using any chemical (Hill, 2006; Esteves and Pereira 2009). Thermal treatment has been industrialized under different processes: Thermowood is carried out with steam in Finland, Plato Wood uses both of steam and heated air in Holland, Rectification with an inert gas in France and OHT with heated oil in Germany (Esteves, 2008).

Earlier studies indicated that thermal treatment reduces the equilibrium moisture content of wood (Jamsa and Viitaniemi 2001; Esteves et al. 2007; Hill et al. 2012), thus improves dimensional stability (Tjeerdsma and Militz 2005; Srinivas and Pandey 2012) and durability (Tjeerdsma et al. 1998; Kamdem et al. 2002; Hakkou et al. 2006). However, thermal treatment reduces the mechanical properties of wood (Bekhta and Niemz 2003; Korkut et al. 2008; Esteves et al. 2014).

Another alternative technology for thermal modification of wood is the thermo-vacuum process. In this process, oxygen, which causes wood combustion, is removed from the reactor by means of a vacuum pump (Sandak et al. 2015). Lin et al. (2018) found that crystallinity of cellulose was increased by increasing in treatment temperature under vacuum. According to Xue-hua et al. (2014), vacuum heat treatment was found promising to improve dimensional stability of wood and keeping mechanical properties at 160 and $200^{\circ} \mathrm{C}$.

Crude tall oil is a major commercial by-product, which is obtained from the soap skimmings after acidification with sulphuric acid in the pulping industry based on kraft process (Rydholm 1965). Nogueira (1996) reported that chemical content of tall oil depends on the age of material, wood species and geographical location and the operations carried out before and during the pulping process. Crude tall oil includes the fatty acids between 40 $60 \%, 40-55 \%$ resin acids, and 5-10\% neutral components (Zachary et al., 1965). Additionally, unsaponifiable substances like sterols, waxes, hydrocarbons are the constituents of tall oil.

It was reported that environmentally friendly treatment with tall oil greatly reduces the capillary water uptake of pine sapwood (Van Eckeveld 2001). Besides, tall oil emulsions could reduce the water uptake even in lower retentions that was found to be equal with crude tall oil, furthermore total amount of tall oil could be halved by emulsion method (Hyvönen et al. 2006). Addition of iron catalyst considerably improved the water repellent efficiency of tall oil treated wood with the enhanced drying properties (Hyvönen et al. 2007). Can and Sivrikaya (2016) found that tall oil solutions with ethanol, methanol, acetone and oil-in-water reduced the water uptake in Scots pine and fir. Lahtela and Karki (2016) impregnated the Scots pine with water repellents in order to enhance the mechanical properties of wood. Tall oil impregnation did not increase the bending strength, however, the reduction was found smaller than that of the reference samples.

There is less research conducted on the improvement of wood properties by tall oil, in addition, combination of tall oil and vacuum heat treatment was not found in the literature. Therefore, the aim of this study was to evaluate the effect of tall oil and vacuum- heat treatment on the physical and mechanical properties of fir and poplar.

\section{Materials and Methods}

Fir (Abies bornmülleriana) and poplar (Populus euramericana cv.) were selected as wood species in the present study. The timbers free of any defects were obtained from sawmill industry in Bartın in Turkey. They were dried until the air-dry moisture content, then cut into small size to use in the experiments. Crude tall oil was obtained as a byproduct from the OYKA pulp and paper mill running according to kraft process in Çaycuma, Turkey. 
Tall oil was dissolved in the ethanol at $10 \%$ and $20 \%$ concentrations respectively for the sole and combined treatments. The samples were first subjected to kiln drying at $103{ }^{\circ} \mathrm{C}$ until the oven-dry weight. Impregnation of the samples was performed under vacuum at $650 \mathrm{mmHg}$ for $30 \mathrm{~min}$. and air pressure at 6 bar for $1 \mathrm{~h}$. After impregnation, the samples were oven-dried at $103{ }^{\circ} \mathrm{C}$ for calculation of weight percentage gain (WPG). Then, oven dried samples were subjected to vacuum heat treatment at $180{ }^{\circ} \mathrm{C}$ and $200{ }^{\circ} \mathrm{C}$ for 1 and 2 hours. WPG was calculated according to the equation below:

WPG $(\%)=\left(\left(\mathrm{W}_{\mathrm{t}}-\mathrm{W}_{0}\right) / \mathrm{W}_{0}\right) \times 100$

where $\mathrm{Wt}$ is the oven dry weight of treated wood and $\mathrm{W}_{0}$ is the oven dry weight of the untreated wood.

\subsection{Water uptake}

The samples were sized to the dimensions of 20x20x10 mm (RxTxL) and were oven-dried before water uptake. Control and treated samples were soaked in the distilled water for 2, 4, 6, 24, 48, 72, 168 and 336 hours. The weight and dimensions of the samples were recorded after each soaking period. Six replicates of control and treated samples were used for each experiment.

Water uptake was calculated by the following equation (1):

$\mathrm{WA}(\%)=\left(\left(\mathrm{W}_{1}-\mathrm{W}_{0}\right) / \mathrm{W}_{0}\right) \times 100$

where $\mathrm{W}_{1}$ is weight of the sample after soaking and $\mathrm{W}_{0}$ is weight of the oven-dried sample.

\subsection{Tangential swelling}

The dimension of the samples was measured by digital caliper in the tangential direction after each soaking. Then, tangential swelling was determined based on the following equation (2):

$\operatorname{TS}(\%)=\left(\left(\mathrm{T}_{1}-\mathrm{T}_{0}\right) / \mathrm{T}_{0}\right) \times 100$

where $T_{1}$ is the tangential length of the sample after water soaking and $T_{0}$ is the tangential length of the ovendried sample.

\subsection{Bending strength (MOR) and Modulus of elasticity (MOE)}

Bending strength of the untreated and impregnated samples was performed based on the TS 2474 (Turkish Standard) and modulus of elasticity (MOE) according to the TS 2478. The dimensions of the samples were 20x20x300 mm (RxTxL) and 90 samples were used in total. Bending strength $(\sigma e)$ was determined from the following equation (3):

$\sigma e=3 \times \mathrm{P}_{\max } \times \mathrm{L} / 2 \times b \times h^{2}\left(\mathrm{~N} / \mathrm{mm}^{2}\right)$

where $P_{\max }$ is the load at the fracture point $(\mathrm{N}), \mathrm{L}$ is span $(\mathrm{mm}), \mathrm{b}$ is width of the sample $(\mathrm{mm})$ and $\mathrm{h}$ is the thickness of the sample (mm). MOE was determined according to the following equation (4):

$\mathrm{MOE}=\Delta \mathrm{F} \times \mathrm{L}^{3} / \Delta \mathrm{f} \times 4 \times \mathrm{b}^{2} \mathrm{~h}^{3}\left(\mathrm{~N} / \mathrm{mm}^{2}\right)$

where $\Delta \mathrm{F}$ is the difference in force in elastic deformation zone $(\mathrm{N})$ and $\Delta \mathrm{f}$ is the deflection $(\mathrm{mm})$.

\subsection{Compression strength}

Compression strength parallel to the fiber was performed according to the principles of the TS 2595 standard. Total of 90 samples with $20 \times 20 \times 30 \mathrm{~mm}$ in size were used for this experiment. Determination of the compression strength was calculated according to following equation (5):

$\sigma b=F / A\left(N / m^{2}\right)$

Where A is the cross-sectional area $\left(\mathrm{mm}^{2}\right)$ of the sample and $\mathrm{F}$ is the maximum force $(\mathrm{N})$.

One-way analysis of variance (ANOVA) was used to determine the statistically significant differences among the means of the groups at $95 \%$ confidence level and Duncan's multiple comparison test subsequently was performed for the evaluation of the mechanical results. 


\section{Results and Discussion}

\subsection{Weight percentage gain}

Weight percentage gain (WPG \%) of the samples was calculated after tall oil (TO) impregnation and the results are given in Table 1 for fir and poplar samples.

Table 1. Mean values of the weight percentage gain (WPG \%) of the samples after tall oil impregnation (values in parentheses indicate the standard deviations).

\begin{tabular}{lcc}
\hline & Fir & Poplar \\
\hline Treatments & WPG $(\%)$ & WPG $(\%)$ \\
\hline $10 \% \mathrm{TO}($ Tall oil $)$ & $23.0(0.5)$ & $22.5(4.7)$ \\
\hline $20 \% \mathrm{TO}$ & $42.2(2.4)$ & $41.7(3.9)$ \\
\hline $180^{\circ} \mathrm{C}(1 \mathrm{~h})$ & - & - \\
\hline $180^{\circ} \mathrm{C}(2 \mathrm{~h})$ & - & - \\
\hline $200^{\circ} \mathrm{C}(1 \mathrm{~h})$ & - & - \\
\hline $200{ }^{\circ} \mathrm{C}(2 \mathrm{~h})$ & - & - \\
\hline $10 \% \mathrm{TO}+180^{\circ} \mathrm{C}(1 \mathrm{~h})$ & $23.8(1.2)$ & $22.9(1.6)$ \\
\hline $10 \% \mathrm{TO}+180^{\circ} \mathrm{C}(2 \mathrm{~h})$ & $23.0(1.2)$ & $21.8(1.9)$ \\
\hline $20 \% \mathrm{TO}+180^{\circ} \mathrm{C}(1 \mathrm{~h})$ & $42.4(3.1)$ & $43.1(1.7)$ \\
\hline $20 \% \mathrm{TO}+180^{\circ} \mathrm{C}(2 \mathrm{~h})$ & $42.9(2.5)$ & $40.9(5.2)$ \\
\hline $10 \% \mathrm{TO}+200^{\circ} \mathrm{C}(1 \mathrm{~h})$ & $23.0(0.3)$ & $22.3(0.9)$ \\
\hline $10 \% \mathrm{TO}+200^{\circ} \mathrm{C}(2 \mathrm{~h})$ & $21.7(1.4)$ & $22.0(1.3)$ \\
\hline $20 \% \mathrm{TO}+200^{\circ} \mathrm{C}(1 \mathrm{~h})$ & $43.2(1.7)$ & $43.1(5.9)$ \\
\hline $20 \% \mathrm{TO}+200^{\circ} \mathrm{C}(2 \mathrm{~h})$ & $41.1(2.5)$ & $41.7(4.0)$ \\
\hline
\end{tabular}

According to the obtained results, fir and poplar wood samples retained approximately the same amount of tall oil (Table 1). WPG showed high similarity with fir and poplar samples impregnated with tall oil at $10 \%$ and $20 \%$ respectively. This means that penetration behavior of fir was similar with poplar wood. On the other hand, increase in tall oil concentration accompanied with the increasing in WPG. The increase was obtained about two fold at $20 \%$ of tall oil compared to $10 \%$ of tall oil. In our earlier study, we found the WPG of $10 \%, 17 \%$ and $26 \%$ respectively for Scots pine treated with tall oil at a rate of 5\%,10\% and 15\% (Sivrikaya and Can 2016).

\subsection{Water uptake}

The water uptake of fir and poplar untreated and treated samples is given in Figures 1 and 2 respectively.

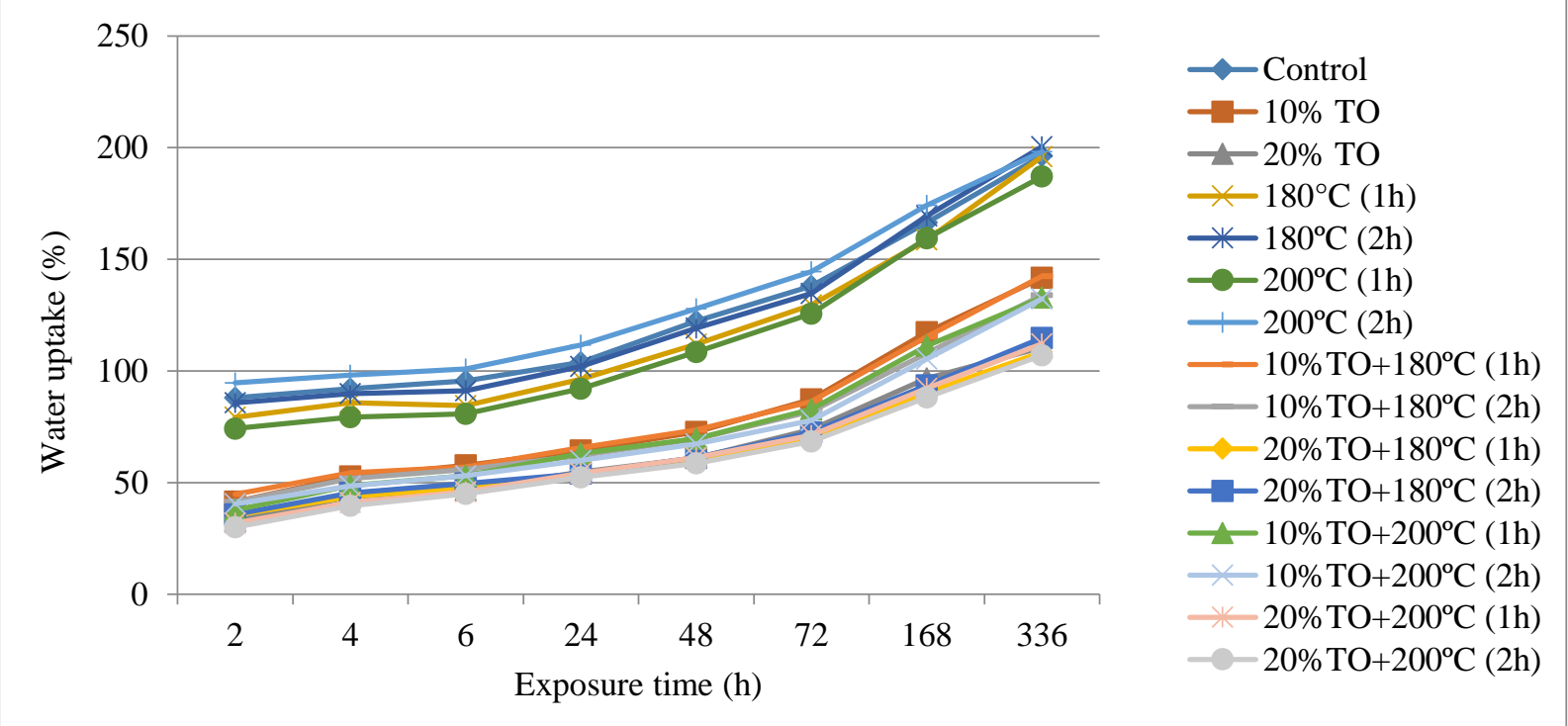

Figure 1. Water uptake for control and treated fir samples subjected to different exposure times. 


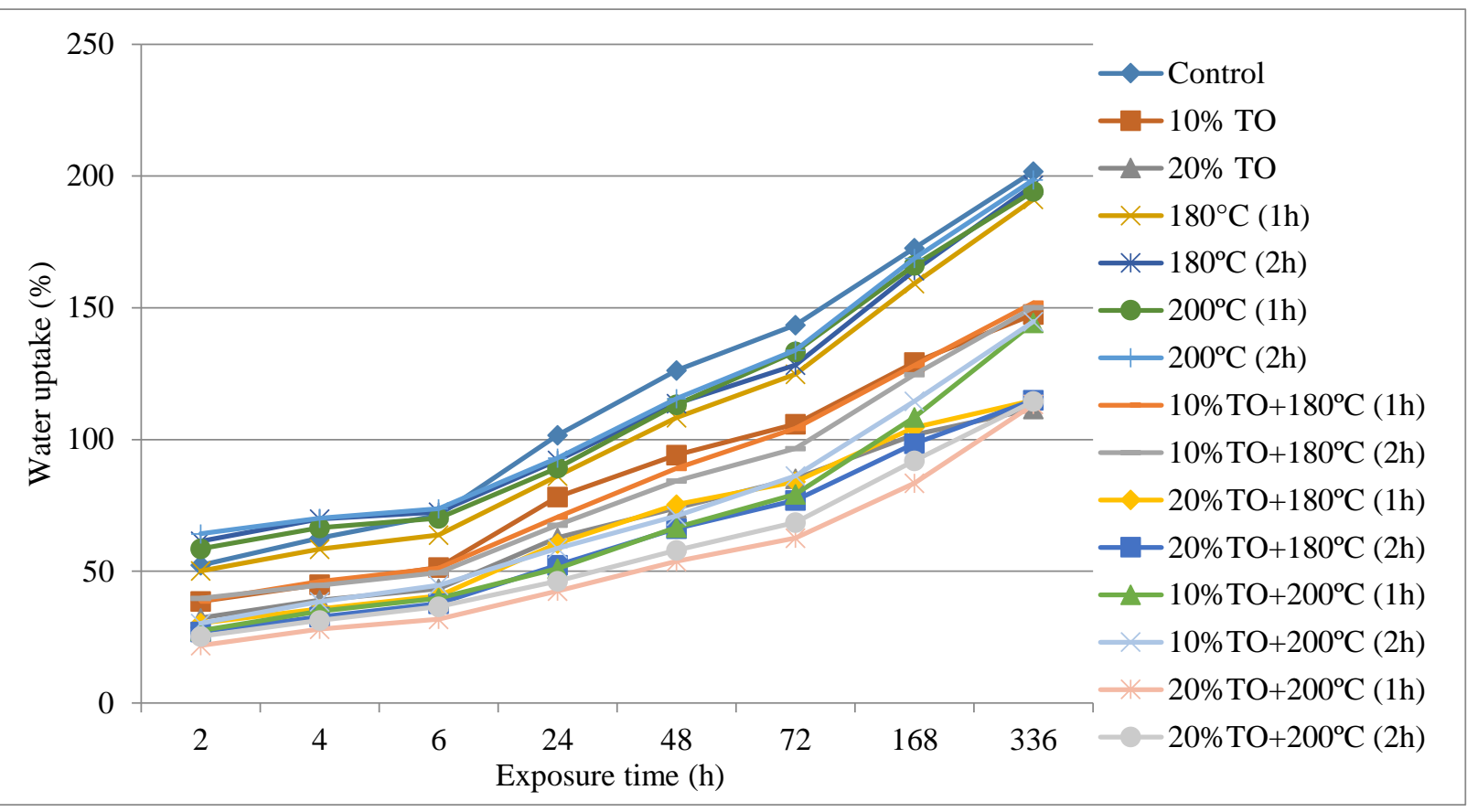

Figure 2. Water uptake for control and treated poplar samples subjected to different exposure times.

Based on the obtained results regarding water uptake in the Figures 1 and 2, fir control samples absorbed more water than poplar control samples in the first hours of the soaking. However, water uptake values of fir and poplar control samples were close to each other after 336 hours. Figure 1 indicates that $20 \% \mathrm{TO}+200{ }^{\circ} \mathrm{C}(2 \mathrm{~h})$ showed the lowest water uptake for all exposure times from $2(30 \%)$ to 336 hours $(107 \%)$. Heat treatment of fir at $200{ }^{\circ} \mathrm{C}(2 \mathrm{~h})$ gave the highest water absorption from the beginning of soaking to the 168th hours, while treatment with $180^{\circ} \mathrm{C}(2 \mathrm{~h})$ had the highest uptake in the last stage.

Overall assessment on Figure 1 demonstrates that samples displayed two different groups during the water uptake period. Control, $180^{\circ} \mathrm{C}(1 \mathrm{~h}), 180{ }^{\circ} \mathrm{C}(2 \mathrm{~h}), 200{ }^{\circ} \mathrm{C}(1 \mathrm{~h})$ and $200{ }^{\circ} \mathrm{C}(2 \mathrm{~h})$ were distinctly different from the other treatments, as a result they showed an upward trend in the Figure 1. As shown from the Figure1, the treatments exhibiting higher water uptake do not involve tall oil. So, this result suggest that tall oil is important in preventing water uptake, resulting in better performance compared to the other treatments without tall oil. In addition, it can be said that higher concentration of tall oil with the higher treatment temperature generally resulted in lower water uptake. For the poplar samples, water uptake ranged from $43 \%\left(20 \% \mathrm{TO}+200{ }^{\circ} \mathrm{C}(2 \mathrm{~h})\right)$ to $102 \%$ (control) at the 24th hour of soaking (Figure 2). After that, the difference among the formulations in terms of water absorption became more clear for longer times. $20 \%$ of tall oil, and its combination with vacuum heating $\left(180{ }^{\circ} \mathrm{C}\right.$ and $\left.200{ }^{\circ} \mathrm{C}\right)$ resulted in higher water resistance compared to other formulations. The results proves that increase in the concentration of tall oil was found to be effective in inhibiting the water uptake of poplar samples (Figure 2). In the study conducted by Can and Sivrikaya (2016), tall oil formulations with different solvents and water emulsion of tall oil resulted in lower water uptake than untreated samples. Water uptake ranged from $38 \%$ to $66 \%$ for $72 \mathrm{~h}$ in Scots pine, and from $61 \%$ to $99 \%$ in fir depending on the formulation type.

It can be concluded from the Figures 1 and 2 that tall oil showed effectiveness in the wood lumen in terms of resistance to water uptake. Hyvönen et al. (2006) stated that closing or filling lumen with tall oil in the wood reduced capillary water uptake. Besides, it was assumed that effectiveness of the treatment might be associated with the location of the oil within the wood (Hyvönen et al. 2006). The oil filling the cell cavities is stored in the interior or exterior surfaces of the wood so that the wood surface shows hydrophobic property (Koski, 2008).

\subsection{Tangential swelling}

Tangential swelling (TG) behavior of control and treated samples for fir and poplar is shown in the Figures 3 and 4. 


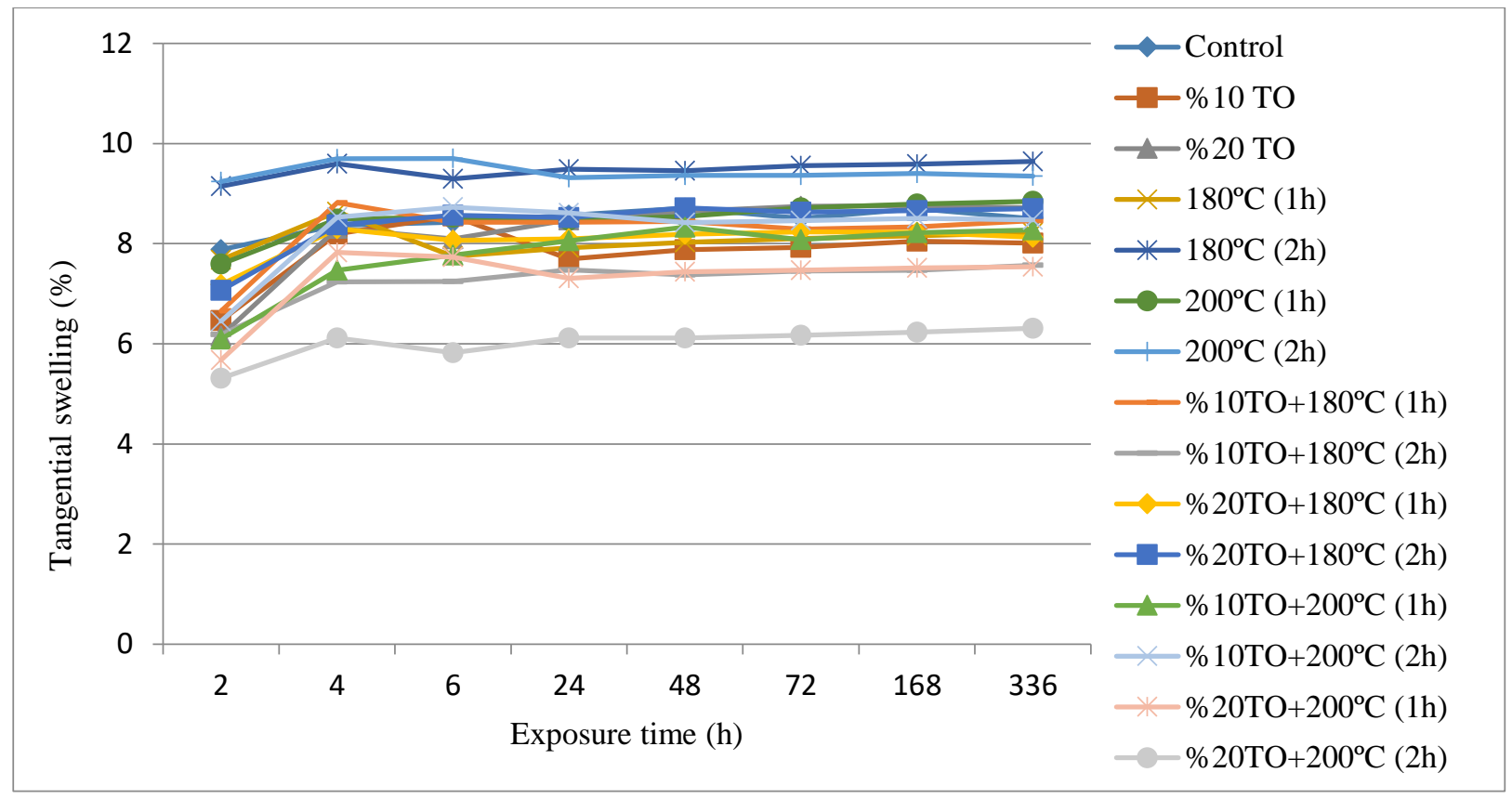

Figure 3. Tangential swelling of fir samples subjected to water soaking.

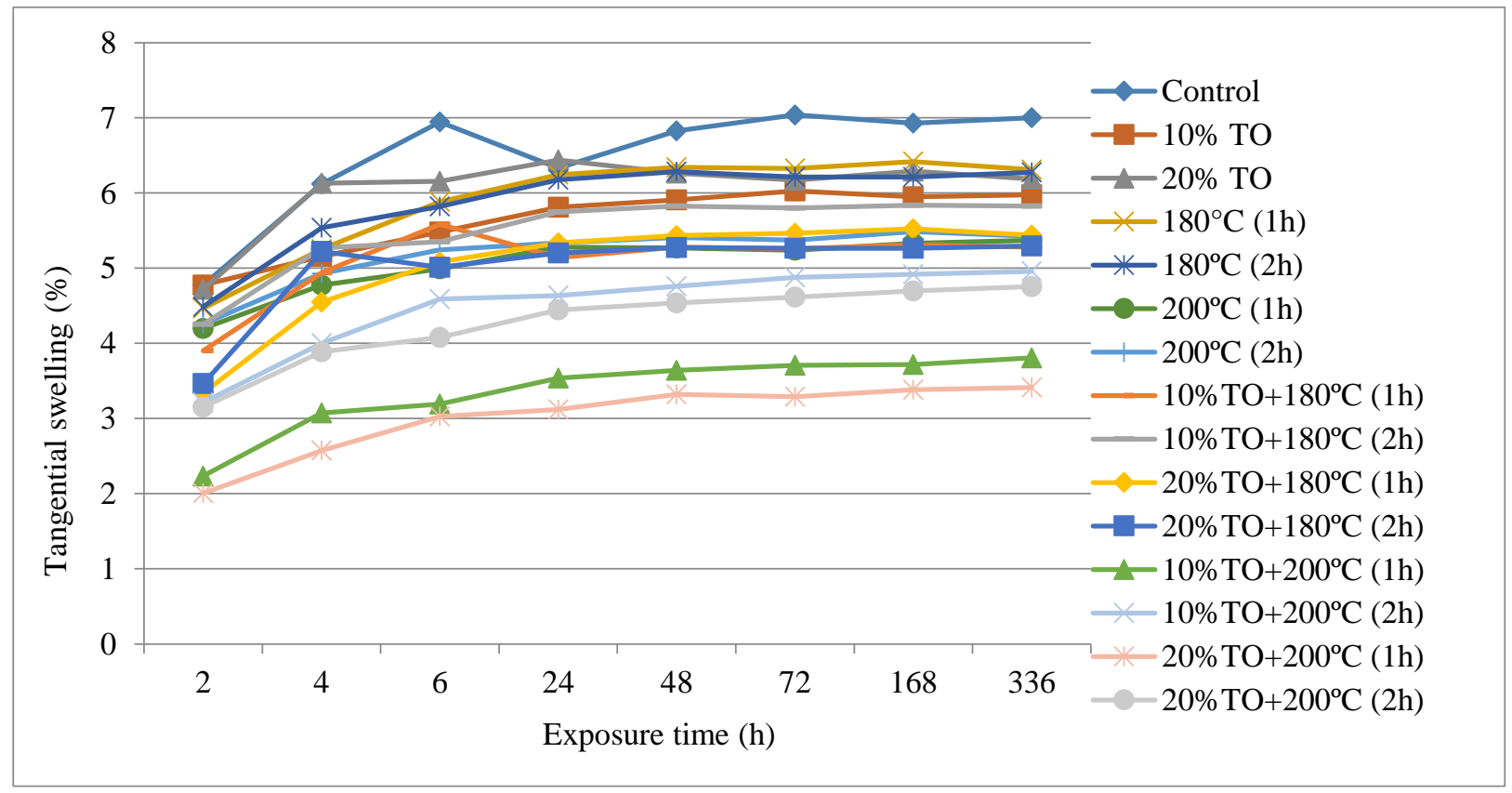

Figure 4. Tangential swelling of poplar samples subjected to water soaking.

Based on the obtained results in Figure 3, TG values in fir samples increased significantly in the 4-hour duration during the soaking, then TG remained almost steady with increasing time. Treatment of fir with $20 \% \mathrm{TO}+200{ }^{\circ} \mathrm{C}$ (2h) had the lowest TG $(6.3 \%)$, while TG for other treatments was over $7 \%$. Figure 4 shows that TG values increased during 24-hour period in poplar samples, after then the change in TG was shown to be very low.

Poplar treatment with $20 \% \mathrm{TO}+200{ }^{\circ} \mathrm{C}$ for $1 \mathrm{~h}(3.4 \%)$ was found to be most successful for restraining the TG, whereas control samples had the highest value $(7 \%)$. The results of the study showed that poplar samples displayed lower TG than fir for all formulations at the end of the exposure period. 


\subsection{Mechanical properties}

Bending strength (MOR) and modulus of elasticity (MOE) values of fir and poplar wood samples are given in Table 2, and the results of compression strength are given in Table 3.

Table 2. Effect of tall oil and vacuum heat treatment on MOR and MOE of fir and poplar (the letters indicate the homogeneous groups; values in parentheses indicate the standard deviations).

\begin{tabular}{|c|c|c|c|c|}
\hline \multirow[b]{2}{*}{ Treatments } & \multicolumn{2}{|c|}{ Fir } & \multicolumn{2}{|c|}{ Poplar } \\
\hline & $\begin{array}{c}\mathrm{MOR} \\
\left(\mathrm{N} / \mathrm{mm}^{2}\right)\end{array}$ & $\begin{array}{c}\mathrm{MOE} \\
\left(\mathrm{N} / \mathrm{mm}^{2}\right)\end{array}$ & $\begin{array}{c}\mathrm{MOR} \\
\left(\mathrm{N} / \mathrm{mm}^{2}\right)\end{array}$ & $\begin{array}{c}\mathrm{MOE} \\
\left(\mathrm{N} / \mathrm{mm}^{2}\right)\end{array}$ \\
\hline Control & $69.3^{\mathrm{a}}(5.8)$ & $6452^{\mathrm{ab}}(451)$ & $63.1^{\text {bcd }}(5.0)$ & $4724^{\mathrm{a}}(300)$ \\
\hline $10 \% \mathrm{TO}$ & $71.8^{\mathrm{ab}}(8.2)$ & $6811^{\mathrm{ab}}(882)$ & $69.0^{\mathrm{d}}(5.0)$ & $5010^{a}(290)$ \\
\hline $20 \% \mathrm{TO}$ & $77.8^{\mathrm{ab}}(5.2)$ & $7129^{\mathrm{b}}(496)$ & $66.4^{\text {bcd }}(8.8)$ & $5063^{\mathrm{ab}}(531)$ \\
\hline $180^{\circ} \mathrm{C}(1 \mathrm{~h})$ & $71.8^{\mathrm{ab}}(10.8)$ & $6632^{\mathrm{ab}}(948)$ & $67.4^{\text {bcd }}(9.6)$ & $5325^{\mathrm{ab}}(617)$ \\
\hline $180^{\circ} \mathrm{C}(2 \mathrm{~h})$ & $74.2^{\mathrm{ab}}(9.1)$ & $6481^{\mathrm{ab}}(554)$ & $68.4^{\mathrm{cd}}(4.4)$ & $5216^{\mathrm{ab}}(251)$ \\
\hline $200^{\circ} \mathrm{C}(1 \mathrm{~h})$ & $78.2^{\mathrm{ab}}(3.2)$ & $7101^{\mathrm{b}}(311)$ & $63.3^{\text {bcd }}(3.4)$ & $5123^{\mathrm{ab}}(598)$ \\
\hline $200^{\circ} \mathrm{C}(2 \mathrm{~h})$ & $75.2^{\mathrm{ab}}(5.7)$ & $6659^{\mathrm{ab}}(390)$ & $53.5^{\mathrm{a}}(6.9)$ & $4978^{\mathrm{a}}(561)$ \\
\hline $10 \% \mathrm{TO}+180^{\circ} \mathrm{C}(1 \mathrm{~h})$ & $74.6^{\mathrm{ab}}(8.7)$ & $6670^{\mathrm{ab}}(449)$ & $64.8^{\text {bcd }}(7.7)$ & $5393^{\mathrm{ab}}(797)$ \\
\hline $10 \% \mathrm{TO}+180^{\circ} \mathrm{C}(2 \mathrm{~h})$ & $71.7^{\mathrm{ab}}(3.5)$ & $6313^{\mathrm{ab}}(651)$ & $71.4^{\mathrm{d}}(9.0)$ & $5440^{\mathrm{ab}}(773)$ \\
\hline $20 \% \mathrm{TO}+180^{\circ} \mathrm{C}(1 \mathrm{~h})$ & $80.6^{\mathrm{b}}(7.1)$ & $7008^{\mathrm{ab}}(555)$ & $70.8^{\mathrm{d}}(5.0)$ & $5461^{\mathrm{ab}}(438)$ \\
\hline $20 \% \mathrm{TO}+180^{\circ} \mathrm{C}(2 \mathrm{~h})$ & $78.5^{\mathrm{ab}}(9.2)$ & $6666^{\mathrm{ab}}(986)$ & $68.8^{\mathrm{d}}(8.6)$ & $5214^{\mathrm{ab}}(736)$ \\
\hline $10 \% \mathrm{TO}+200^{\circ} \mathrm{C}(1 \mathrm{~h})$ & $70.3^{\mathrm{ab}}(9.9)$ & $6156^{a}(907)$ & $70.5^{\mathrm{d}}(7.4)$ & $5436^{\mathrm{ab}}(875)$ \\
\hline $10 \% \mathrm{TO}+200^{\circ} \mathrm{C}(2 \mathrm{~h})$ & $77.2^{\mathrm{ab}}(6.1)$ & $6752^{\mathrm{ab}}(290)$ & $59.3^{\text {abc }}(8.7)$ & $5562^{\mathrm{ab}}(279)$ \\
\hline $20 \% \mathrm{TO}+200^{\circ} \mathrm{C}(1 \mathrm{~h})$ & $78.0^{\mathrm{ab}}(10.5)$ & $7085^{\mathrm{b}}(735)$ & $71.1^{\mathrm{d}}(6.6)$ & $5448^{a b}(780)$ \\
\hline $20 \% \mathrm{TO}+200^{\circ} \mathrm{C}(2 \mathrm{~h})$ & $77.2^{\mathrm{ab}}(7.1)$ & $6657^{\mathrm{ab}}(412)$ & $58.4^{\mathrm{ab}}(3.9)$ & $5911^{\mathrm{b}}(738)$ \\
\hline
\end{tabular}

Table 2 indicates that tall oil impregnation increased the bending strength of both fir and poplar samples compared to control ones. The increasing in bending strength was as follows: $3.7 \%$ for the fir and $9.4 \%$ in the poplar samples treated with tall oil at $10 \%$. In the case of the treatment with $20 \%$ of tall oil, increasing was 12.2 $\%$ for the fir samples, and 5.2\% for the poplar. Increase in bending strength in fir ranged from $3.6 \%$ to $7.1 \%$ at $180^{\circ} \mathrm{C}$, while from $8.6 \%$ to $12.9 \%$ at $200{ }^{\circ} \mathrm{C}$. Surini et al. (2012) found no significant effect on wood properties of maritime pine at the temperatures up to $200^{\circ} \mathrm{C}$ under vacuum. However, they obtained important decrease in MOR which were $42.5 \%$ and $62.5 \%$ at the temperatures of 230 and $260^{\circ} \mathrm{C}$ respectively. The other formulations with tall oil also increased the bending strength of fir samples, the maximum increase was obtained by $20 \%$ $\mathrm{TO}+180{ }^{\circ} \mathrm{C}(1 \mathrm{~h})$ at a rate of $16.3 \%$. An apparent finding from the Table 2 shows that MOR of all the treatments except for control and $20 \% \mathrm{TO}+180{ }^{\circ} \mathrm{C}(1 \mathrm{~h})$ statistically were in the same homogeneous group in fir due to the similar results.

In the poplar samples, combination treatments including oil and vacuum heating generally gave low MOR values in the case of $2 \mathrm{~h}$ duration. Based on the findings in this study, MOR of the samples is not affected by vacuum heat treatment that can be explained by the treatment process where application of vacuum causes an oxygen-free environment which inhibits the degradation. However, the same situation was not realized for poplar in the case of vacuum heat treatment at $200{ }^{\circ} \mathrm{C}$ for $2 \mathrm{~h}$ which gave the lowest result. In a previous study, we found that MOE and MOR were not affected by solely vacuum heat treatment at the temperatures of 180 and $200{ }^{\circ} \mathrm{C}$ for $2 \mathrm{~h}$ in Scots pine (Sivrikaya et al. 2020). Norway spruce and fir, thermally modified by TERMOVUOTO process in the range of 160 to $220{ }^{\circ} \mathrm{C}$ under vacuum conditions showed no significant decrease in mechanical properties. This result was associated with the idea, indicating the evacuation of thermal degradation products from wood by vacuum, consequently decreasing the degradation in the hemicelluloses 
(Allegretti et al. 2012). Accordingly, Candelier et al. (2013) obtained higher MOR and MOE with heat treated beech wood under vacuum comparatively to heat treated ones under nitrogen. The better performance of vacuum heat treatment was explained by the lower degradation of hemicelluloses which is associated with lower decrease of mechanical properties. Xue-hua et al. (2014) studied with eucalyptus wood from 80 to $280{ }^{\circ} \mathrm{C}$ for $4 \mathrm{~h}$ under vacuum, found that MOE and MOR initially increased, but then decreased rapidly. They found that MOE increased by $25.2 \%$ at $200{ }^{\circ} \mathrm{C}$, while MOR increased by $6.5 \%$ at $160{ }^{\circ} \mathrm{C}$ compared to untreated samples. In another study, black pine was subjected to thermal modification in vacuum, nitrogen, and air at temperatures of $180{ }^{\circ} \mathrm{C}, 200{ }^{\circ} \mathrm{C}$ and $220{ }^{\circ} \mathrm{C}$. MOE and MOR were the least affected by vacuum heat treatment (Bal 2018).

Modulus elasticity in fir samples increased with the increasing of tall oil concentration. Sole treatments with vacuum heating for $2 \mathrm{~h}$ revealed lower MOE than $1 \mathrm{~h}$ at the temperatures of $180{ }^{\circ} \mathrm{C}$ and $200{ }^{\circ} \mathrm{C}$. Increasing in treatment time decreased the MOE in most cases for the combined treatments. It can be said about the MOE of poplar that combined treatments with tall oil increased the MOE higher than the sole treatments with tall oil (Table 2). Increasing in temperature slightlylowered the MOE of poplar in the case of sole treatments with vacuum heating. However, Overall treatments with poplar revealed higher MOE than control. It was previously explained that slight increase in MOE might be due to the degradation of amorphous cellulose and increase in the relative crystallinity with high temperature. In addition, degradation of hemicellulose, ramification of lignin and crystallization of cellulose affects the mechanical properties (Kocaefe et al. 2008).

Table 3. Effect of tall oil and vacuum heat treatment on compression strength of fir and poplar (the letters indicate the homogeneous groups; values in parentheses indicate the standard deviations).

\begin{tabular}{ccc}
\hline & \multicolumn{2}{c}{ Compression strength $\left(\mathrm{N} / \mathrm{mm}^{2}\right)$} \\
\hline Treatments & Fir & Poplar \\
\hline Control & $39.3^{\mathrm{a}}(3.3)$ & $35.2^{\mathrm{a}}(2.8)$ \\
\hline $10 \% \mathrm{TO}$ & $43.7^{\mathrm{bcdef}}(3.3)$ & $36.9^{\mathrm{ab}}(1.0)$ \\
\hline $20 \% \mathrm{TO}$ & $41.9^{\mathrm{abc}}(1.3)$ & $37.6^{\mathrm{abc}}(0.6)$ \\
\hline $180^{\circ} \mathrm{C}(1 \mathrm{~h})$ & $43.7^{\mathrm{bcdef}}(3.1)$ & $36.8^{\mathrm{ab}}(2.6)$ \\
\hline $180^{\circ} \mathrm{C}(2 \mathrm{~h})$ & $42.0^{\mathrm{abc}}(3.5)$ & $38.7^{\mathrm{bc}}(1.8)$ \\
\hline $200^{\circ} \mathrm{C}(1 \mathrm{~h})$ & $46.9^{\mathrm{fg}}(2.6)$ & $42.1^{\mathrm{def}}(2.9)$ \\
\hline $200^{\circ} \mathrm{C}(2 \mathrm{~h})$ & $46.4^{\mathrm{efg}}(1.9)$ & $40.2^{\mathrm{cd}}(1.9)$ \\
\hline $10 \% \mathrm{TO}+180^{\circ} \mathrm{C}(1 \mathrm{~h})$ & $42.7^{\mathrm{abcde}}(3.0)$ & $40.5^{\mathrm{cde}}(2.6)$ \\
\hline $10 \% \mathrm{TO}+180^{\circ} \mathrm{C}(2 \mathrm{~h})$ & $40.6^{\mathrm{ab}}(1.6)$ & $42.9^{\mathrm{def}}(3.5)$ \\
\hline $20 \% \mathrm{TO}+180^{\circ} \mathrm{C}(1 \mathrm{~h})$ & $45.9^{\mathrm{cdefg}}(2.9)$ & $40.7^{\mathrm{cde}}(1.2)$ \\
\hline $20 \% \mathrm{TO}+180^{\circ} \mathrm{C}(2 \mathrm{~h})$ & $42.1^{\mathrm{abcd}}(3.1)$ & $43.0^{\mathrm{def}}(2.5)$ \\
\hline $10 \% \mathrm{TO}+200^{\circ} \mathrm{C}(1 \mathrm{~h})$ & $49.8^{\mathrm{g}}(2.4)$ & $43.5^{\mathrm{def}}(3.3)$ \\
\hline $10 \% \mathrm{TO}+200^{\circ} \mathrm{C}(2 \mathrm{~h})$ & $43.8^{\mathrm{bcdef}}(1.6)$ & $43.8^{\mathrm{ef}}(1.2)$ \\
\hline $20 \% \mathrm{TO}+200^{\circ} \mathrm{C}(1 \mathrm{~h})$ & $46.2^{\mathrm{defg}}(4.0)$ & $47.6^{\mathrm{g}}(3.2)$ \\
\hline $20 \% \mathrm{TO}+200^{\circ} \mathrm{C}(2 \mathrm{~h})$ & $44.4^{\mathrm{bcdef}}(1.9)$ & $44.5^{\mathrm{f}}(2.7)$ \\
\hline
\end{tabular}

It can be concluded that all treatments had a positive impact on the fir and poplar samples for improving the compression strength, compared to the control (Table 3). This increase showed variation depending on the treatments and parameters such as temperature and duration. The maximum compression strength was obtained by the formulation of $10 \% \mathrm{TO}+200{ }^{\circ} \mathrm{C}(1 \mathrm{~h})$ in the fir samples and by $20 \% \mathrm{TO}+200{ }^{\circ} \mathrm{C}(1 \mathrm{~h})$ in the poplar samples.

A remarkable finding obtained with the fir subjected to the tall oil and heat treatment was that, compression strength increased with the increasing in temperature, but decreased with the increasing in treatment time for each formulation.

Based on the poplar samples, a small difference was found between 10 and $20 \%$ of tall oil treatment in terms of compression strength. The increase in compression strength ranged from $4.6 \%$ to $35.5 \%$ depending on the treatment type. The best result was obtained by the treatment with $20 \% \mathrm{TO}+200{ }^{\circ} \mathrm{C}$ for $1 \mathrm{~h}$, which showed difference from the other formulations (Table 3).

It can be said that tall oil treatment and vacuum heating at higher temperature $\left(200{ }^{\circ} \mathrm{C}\right)$ gave better results regarding compression strength than other formulations for the poplar samples.. 
Bak and Nemeth (2012), reported that oil-heat treatment with different vegetable oils such as sunflower, linseed and rape seed oil for $2 \mathrm{~h}, 4 \mathrm{~h}$ and $6 \mathrm{~h}$ increased the compression strength by $15-25 \%$ in poplar with the increase in temperature and time. Accordingly, Cheng et al. (2014) found increasing in compression strength for poplar samples after oil heat treatment, and this was attributed to the uptake of high oil which caused to the thickening of fibers and enhancing of compression strength parallel to the grain.

In addition it was expressed that oxygen can be separated from wood by oil during heat treatment, thus prevents the occurrence of oxidative process causing reduction in the strength properties of the treated wood (Dubey et al. 2011; Lee et al. 2018).

\section{Conclusions}

Combined treatment of tall oil and vacuum heat treatment on physical and mechanical properties of wood was investigated in this study. WPG increased in fir and poplar samples with the increasing of tall oil ratio. Tall oil was found effective in preventing water uptake during the soaking test. Treatments with tall oil resulted in lower water uptake compared to sole vacuum heat treatment.

Generally, tall oil and vacuum heat treatment had a positive impact on the bending strength and modulus of elasticity. Overall treatments with fir and poplar improved the compression strength compared to the untreated samples. Vacuum heat treatment may be recommended in the places of use where mechanical properties are important.

\section{References}

1. Allegretti, O., Brunetti, M., Cuccui, I., Ferrari, S., Nocetti, M., Terziev, N. (2012). Thermo-vacuum modification of spruce (Picea abies Karst.) and fir (Abies alba Mill.) wood. BioResources, 7(3), 36563669.

2. Bak, M., Nemeth, R. (2012). Modification of wood by oil heat treatment. International Scientific Conference on Sustainable Development \& Ecological Footprint, March 26-27, Sopron, Hungary

3. Bal, B.C. (2018). A Comparative study of some of the mechanical properties of pine wood heat treated in vacuum, nitrogen, and air atmospheres. BioResources, 13(3), 5504-5511.

4. Bekhta, P., Niemz, P. (2003). Effect of high temperature on the change in color, dimensional stability and mechanical properties of spruce wood. Holzforschung, 57(5), 539-546.

5. Can, A., Sivrikaya, H. (2016). Dimensional stabilization of wood treated with tall oil dissolved in different solvents. Maderas. Ciencia y tecnología, 18(2), 317-324.

6. Candelier, K., Dumarçay, S., Pétrissans, A., Gérardin, P., Pétrissans, M. (2013). Comparison of mechanical properties of heat treated beech wood cured under nitrogen or vacuum. Polymer degradation and stability, 98(9), 1762-1765.

7. Cheng, D., Chen, L., Jiang, S., Zhang, Q. (2014). Oil uptake percentage in oil-heat-treated wood, its determination by Soxhlet extraction, and its effects on wood compression strength parallel to the grain. BioResources, 9(1), 120-131.

8. Dubey, M. K., Pang, S., Walker, J. (2011). Effect of oil heating age on colour and dimensional stability of heat treated Pinus radiata. European Journal of Wood and Wood Products, 69(2), 255-262.

9. Esteves, B. (2008). Pine wood modification by heat treatment in air. BioResources, 142-154.

10. Esteves, B., Marques, A. V., Domingos, I., Pereira, H. (2007). Influence of steam heating on the properties of pine (Pinus pinaster) and eucalypt (Eucalyptus globulus) wood. Wood science and technology, 41(3), 193.

11. Esteves, B., Pereira, H. (2009). Wood modification by heat treatment: A review. BioResources, 4(1), 370-404.

12. Esteves, B., Nunes, L., Domingos, I., Pereira, H. (2014). Comparison between heat treated sapwood and heartwood from Pinus pinaster. European Journal of Wood and Wood Products, 72(1), 53-60.

13. Hakkou, M., Pétrissans, M., Gérardin, P., Zoulalian, A. (2006). Investigations of the reasons for fungal durability of heat-treated beech wood. Polymer degradation and stability, 91(2), 393-397.

14. Hill C.A.S. (2006). Wood modification-chemical, thermal and other processes. Wiley series in renewable resources. John Wiley \& Sons, Ltd, p. 239

15. Hill, C. A., Ramsay, J., Keating, B., Laine, K., Rautkari, L., Hughes, M., Constant, B. (2012). The water vapour sorption properties of thermally modified and densified wood. Journal of Materials Science, 47(7), 3191-3197. 
16. Hyvönen, A., Piltonen, P., Niinimäki, J. (2006). Tall oil/water-emulsions as water repellents for Scots pine sapwood. Holz als Roh-und Werkstoff, 64(1), 68-73.

17. Hyvönen, A., Nelo, M., Piltonen, P., Niinimäki, J. (2007). Using the emulsion technique and an iron catalyst to enhance the wood protection properties of tall oil. Holz als Roh-und Werkstoff, 65(3), 247-249.

18. Jamsa, S., Viitaniemi, P. (2001). Heat treatment of wood - Better durability without chemicals. Review on heat treatments of wood, Proceedings of the special seminar of COST Action E22, Antibes, France

19. Kamdem, D. P., Pizzi, A., Jermannaud, A. (2002). Durability of heat-treated wood. Holz als Roh-und Werkstoff, 60(1), 1-6.

20. Kocaefe, D., Poncsak, S., Boluk, Y. (2008). Effect of thermal treatment on the chemical composition and mechanical properties of birch and aspen. BioResources, 3(2), 517-537.

21. Korkut, S., Akgül, M., Dündar, T. (2008). The effects of heat treatment on some technological properties of Scots pine (Pinus sylvestris L.) wood. Bioresource Technology, 99(6), 1861-1868.

22. Koski, A., (2008). Applicability of Crude Tall Oil for Wood Protection, PhD Thesis, Faculty of Technology, Department of Process and Environmental Engineering, University of Oulu, Oulu, Finland, Acta Univ. Oul. C 293.

23. Lahtela, V., Kärki, T. (2016). Effects of impregnation and heat treatment on the physical and mechanical properties of Scots pine (Pinus sylvestris) wood. Wood Material Science \& Engineering, 11(4), 217-227.

24. Lee, S. H., Ashaari, Z., Lum, W. C., Halip, J. A., Ang, A. F., Tan, L. P., Chin, K.L., Tahir, P. M. (2018). Thermal treatment of wood using vegetable oils: A review. Construction and Building Materials, $181,408-419$.

25. Lin, B. J., Colin, B., Chen, W. H., Pétrissans, A., Rousset, P., Pétrissans, M. (2018). Thermal degradation and compositional changes of wood treated in a semi-industrial scale reactor in vacuum. Journal of Analytical and Applied Pyrolysis, 130, 8-18.

26. Nogueira, J. M. F. (1996). Refining and separation of crude tall-oil components. Separation science and technology, 31(17), 2307-2316.

27. Rydholm, S.A. (1965). Pulping Processes. John Wiley\&Sons, New York.

28. Sandak, A., Sandak, J., Allegretti, O. (2015). Quality control of vacuum thermally modified wood with near infrared spectroscopy. Vacuum, 114, 44-48.

29. Sivrikaya, H., Can, A. (2016). Effect of weathering on wood treated with tall oil combined with some additives. Maderas. Ciencia y tecnología, 18(4), 723-732.

30. Sivrikaya, H., Hosseinpourpia, R., Ahmed, S. A., Adamopoulos, S. (2020). Vacuum-heat treatment of Scots pine (Pinus sylvestris L.) wood pretreated with propanetriol. Wood Material Science \& Engineering, 1-9.

31. Srinivas, K., Pandey, K. K. (2012). Effect of heat treatment on color changes, dimensional stability, and mechanical properties of wood. Journal of Wood Chemistry and Technology, 32(4), 304-316.

32. Surini, T., Charrier, F., Malvestio, J., Charrier, B., Moubarik, A., Castéra, P., Grelier, S. (2012). Physical properties and termite durability of maritime pine Pinus pinaster Ait., heat-treated under vacuum pressure. Wood Science and Technology, 46(1-3), 487-501.

33. Tjeerdsma, B. F., Boonstra, M., Pizzi, A., Tekely, P., Militz, H. (1998). Characterisation of thermally modified wood: molecular reasons for wood performance improvement. Holz als Roh-und Werkstoff, 56(3), 149.

34. Tjeerdsma, B. F., Militz, H. (2005). Chemical changes in hydrothermal treated wood: FTIR analysis of combined hydrothermal and dry heat-treated wood. Holz als roh-und Werkstoff, 63(2), 102-111.

35. TS 2474 (1976). Wood determination of ultimate strength in static bending. Turkish standard Institute, Ankara, Turkey.

36. TS 2478 (1976). Wood determination of modulus of elasticity in static bending. Turkish standard Institute, Ankara, Turkey.

37. TS 2595 (1976). Wood determination of ultimate stress in compression parallel to grain. Turkish standard Institute, Ankara, Turkey.

38. Xue-hua, W., Ben-hua, F., Jun-liang, L. (2014). Effect of vacuum heat treatment temperature on physical and mechanical properties of Eucalyptus pellita wood. Wood and Fiber Science, 46(3), 368-375.

39. Van Eckeveld, A. (2001). Natural oils as water repellents for Scots pine. Wageningen University, Thesis AV 2001-15, 30 pages.

40. Zachary, L. G., Bajak, H. W., Eveline, F. J. (1965). Tall oil and its uses. F.W. Dodge Co. 